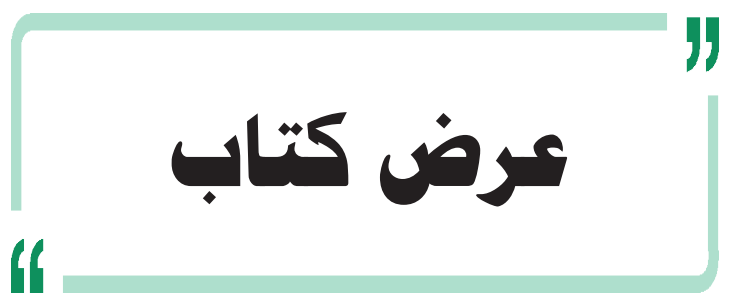





\section{بطاقة الأداء المتوازن المستدام}

تأليف: د. عريوة محاد

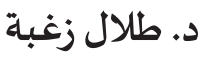

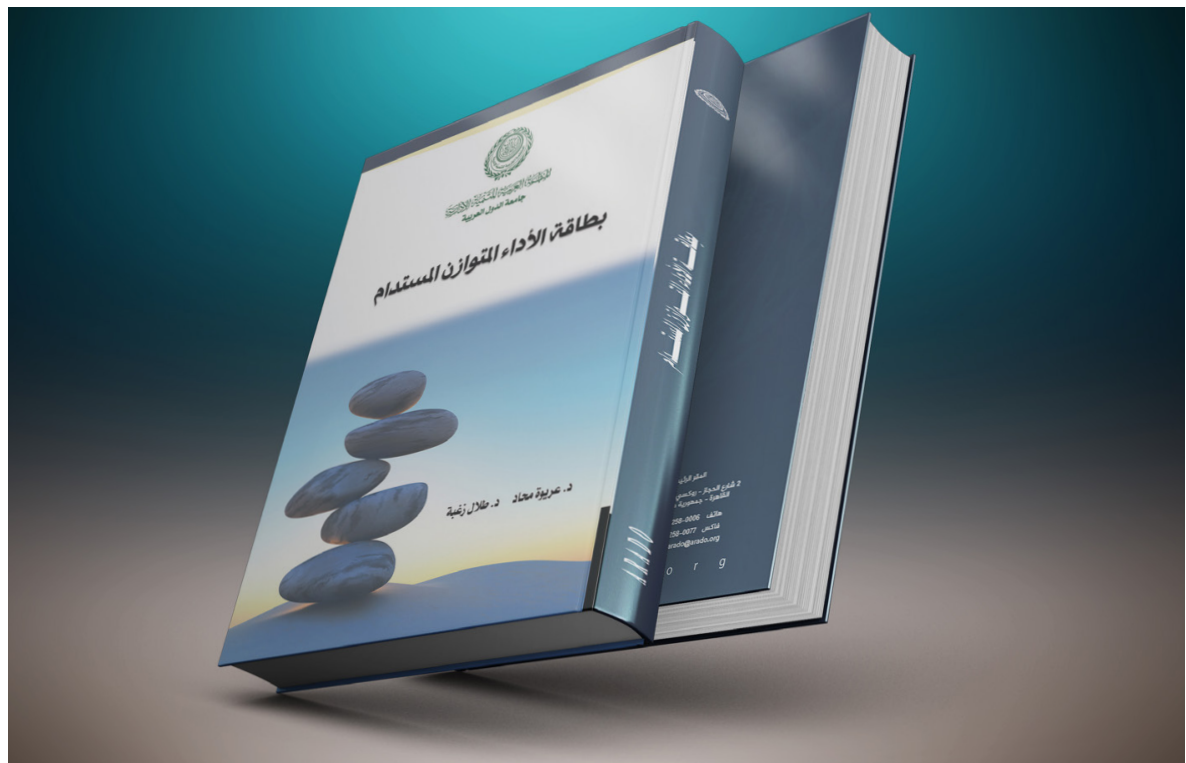

\section{الناشر: المنظمة العربية للتنمية الإدارية جامعة الدول العربية (القاهرة، 2020)}

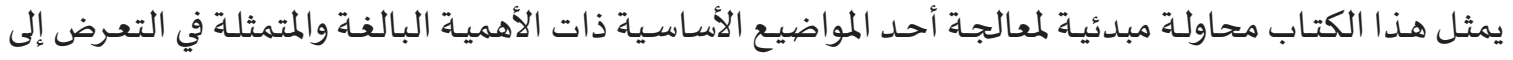

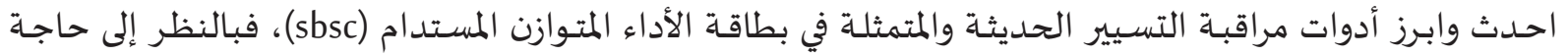

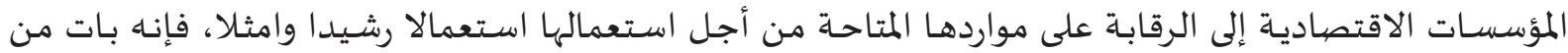

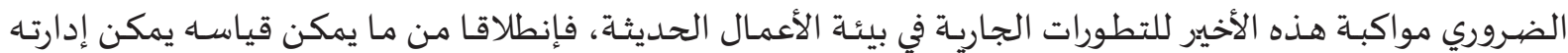

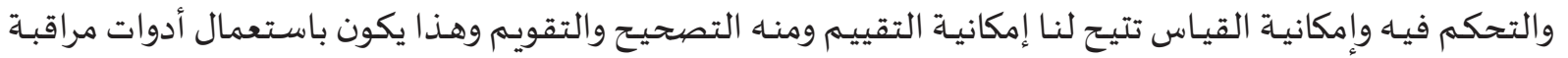

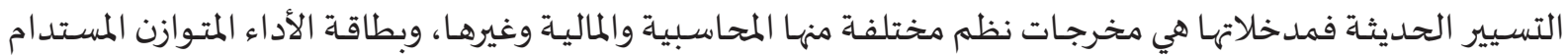

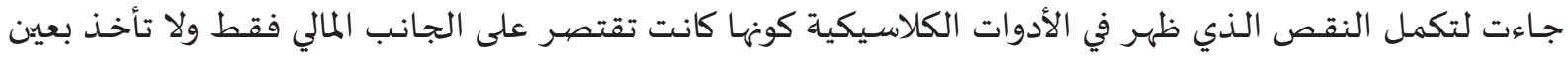

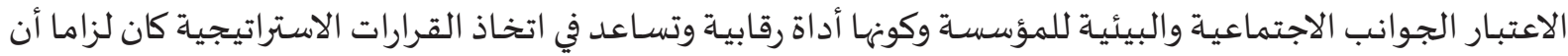

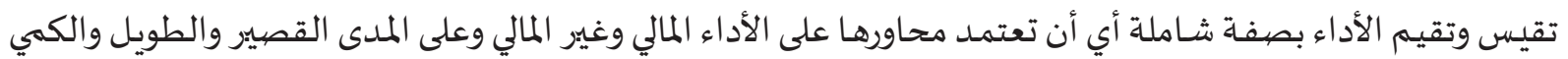

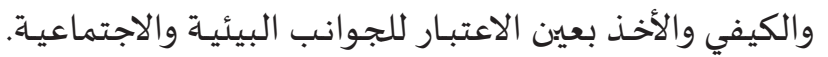

$$
\text { وفي هذا السياق تم تقسيم هذا الكتاب كما يلي: }
$$

الجزء الأول: مدخل للأداء من حيث القياس والتقييم والإدارة.

$$
\text { الجزء الثاني: بطاقة الأداء المتوازن المستدام. }
$$

الجزء الثالث: مؤشرات قياس الأداء لمحاور بطاقة الأداء المتوازن المستدام. 
